\title{
Development of A Study Module on and Pedagogical Approaches to Industrial Environmental Engineering and Sustainability in Mozambique
}

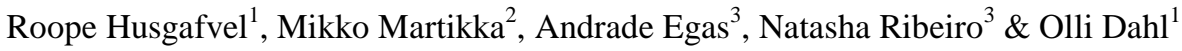 \\ ${ }^{1}$ Clean Technologies Research Group, Department of Bioproducts and Biosystems, School of Chemical Engineering, \\ Aalto University, Finland \\ ${ }^{2}$ Environment Center, City of Helsinki, Finland \\ ${ }^{3}$ Forestry Department, Faculty of Agronomy and Forestry Eduardo, Mondlane University \\ Correspondence: Roope Husgafvel, Clean Technologies Research Group, Department of Bioproducts and Biosystems, \\ School of Chemical Engineering, P.O. Box 16300, 00076, Aalto University, Finland. Tel: 35-84-0097-0402
}

Received: February 13, 2017

Accepted: March 6, 2017

Online Published: March 7, 2017

doi:10.5430/ijhe.v6n2p50

URL: https://doi.org/10.5430/ijhe.v6n2p50

\begin{abstract}
Addressing the sustainability challenges in the forest sector in Mozambique requires capacity building for higher education and training of new skilled expert and future decision-makers. Our approach was to develop a study module on and pedagogical approaches to industrial environmental engineering and sustainability. The idea was to develop a joint module that would eventually become a part of both $\mathrm{PhD}$ and $\mathrm{MSc}$ programmes in the Eduardo Mondlane University (UEM) in Mozambique. The basis of our development work encompassed the local priorities as identified by the UEM staff, UEM competencies in forestry engineering and the experience of the Aalto University in higher education in the fields of environmental engineering, sustainability and forest products technology. From the beginning, public authorities and industry/company representatives were involved in the development process to advance the created benefits in terms of sustainable development in Mozambique. The result of the joined work by these two higher education institutions was a study module that has been teached and completed by a class of MSc students as a part of the official UEM curricula.
\end{abstract}

Keywords: Sustainability, Industrial environmental engineering, Mozambique, Study module, Pedagogy

\section{Introduction}

Mozambique has significant development, economic and political challenges (World Bank, 2017). In addition, the Worldwide Governance Indicators scores indicate that focus is needed on government effectiveness, rule of law and regulatory quality (Worldwide Governance Indicators, 2012). The Human Development Index also indicates the existence of education, sustainability, gender equality and poverty challenges (The Human Development Index, 2013). The achievement of the UN Millennium Development Goals (United Nations [UN], 2013a,b) in Mozambique requires improvement of environmental sustainability including reforestation investments and associated education. It is noteworthy that the agricultural sector provides employment for $80 \%$ of the workforce. Additionally, participation in the United Nations Programme on Reducing Emission from Deforestation and Forest Degradation requires focus on e.g. forest tenure and local land use and ownership aspects (UN-REDD+, 2013). For example, development of better national and local statistics could be advanced through training and education supported by reliable knowledge bases covering data from local participatory and/or community-based inventories.

Sustainable development in the forest sector in Mozambique requires focus on environmental, economic and social aspects and it is important that supports this line of competence and associated novel skills. Contemporary policy priorities (Plan of Action for the Green Economy, 2013) in Mozambique highlight the need for sustainable use of natural resources and enhanced focus on clean, low carbon and socially inclusive approaches. Addressing critical challenges such as deforestation, sufficient monitoring capacity, protection of forests and locally sustainable forest management and local benefits (e.g. taxes) is essential. In accordance with the Yaounde Ministerial Declaration on African Forest Law Enforcement and Governance (AFLEG 2003), Mozambique is committed to promote good governance, sustainable forest management and capacity building for forest law enforcement and governance.

Between 2007-2012, a lot of logging permit payments were missed due to large volumes of unlicensed wood destined for both export and domestic consumption (Faculty of Agronomy and Forestry Engineering [FAEF], 2013). Therefore, 
promotion of more sustainable utilization wood is among the development priorities in Mozambique encompassing focus on e.g. sustainable forest management practices, effective law enforcement measures, more efficient processing and harvesting technologies and significantly increased use of lesser used species. In general, illegal logging should be monitored better in the future and the role of fast growing plantations should be enhanced. According to the Environmental Investigation Agency (2013), huge amounts of timber was illegally exported in 2012 and they recommended that illegal timber trade should be controlled including use of economic measures and that forest law increased in order to enhance capacity to fund sustainable forest management, forest law enforcement and community support initiatives.

According to Nhantumbo et al. (2013), Mozambique is among the most forested countries in Africa and even up to 80\% of national energy use is supported by the forest sector (fuel wood and charcoal). There is a growing interest to utilize currently non-productive forest lands through reforestation and to eventually develop associated forest industry. This would also create employment and revenues for the government. However, there are many challenges threatening sustainable forest sector development such as illegal logging, uncontrolled forest fires, severe poverty and slash and burn agriculture. Other issues that require focus include e.g. local interests/benefits and increasing consumption and demand trends. Locally driven approaches need to be supported by more secure commercial resource rights, provision of technology and services, stronger entrepreneurship and creation of stronger business capacity (Nhantumbo et al., 2013).

Cooperation around 2010 was finally officially started in 2013 when the "Higher education and capacity-development for sustainability and clean technologies in the forest sector in Mozambique" project was started (Aalto University, 2017). This institutional cooperation and capacity building project was a part of the Higher Education Institutions Institutional Cooperation Instrument (HEI ICI) administered by Centre for International Mobility (CIMO) and funded by Ministry for Foreign Affairs of Finland. The idea of the UEM-Aalto cooperation (Figure 1.) was to address the emerging sustainability challenges particularly in the forest sector and the key goals comprised:

- To jointly develop a study module and associated curriculum on industrial environmental engineering covering sustainability topics and clean technology aspects.

- To plan and carry out measures to enhance staff competence and skills related to the module topics and issues.

- To build UEM networks and capacity regarding its competence to provide services for industry and companies and to support national sustainable development efforts in the field of natural resources.

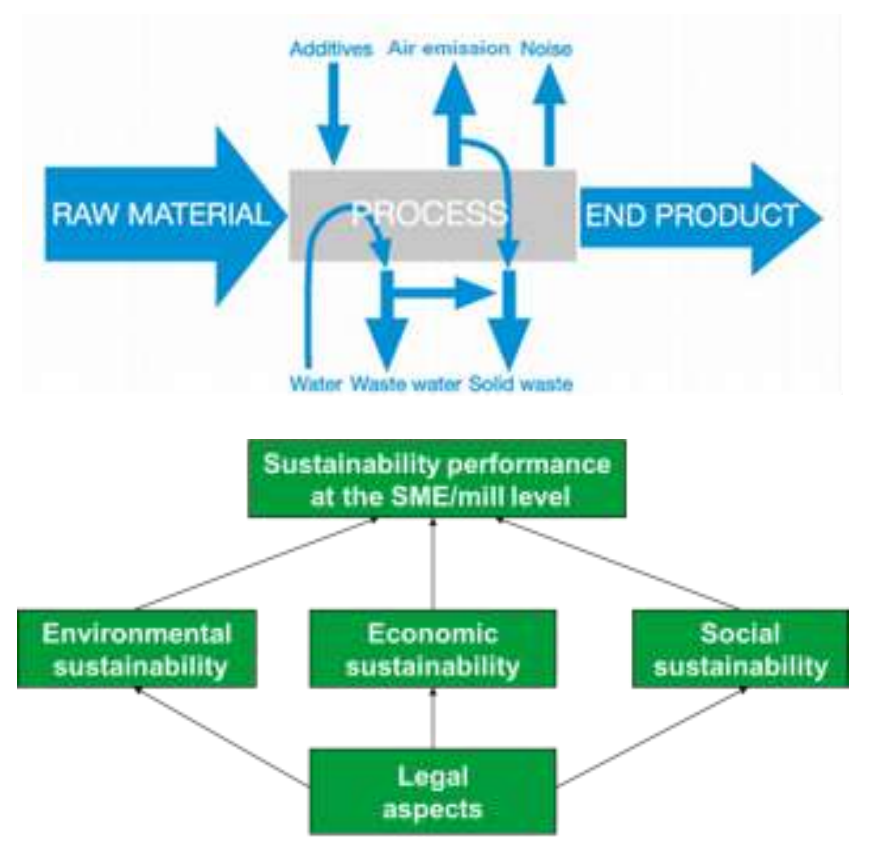

Figure 1. (a) Environmental performance at the company/mill level.

(b) The broad approach to sustainability performance (small and medium-sized enterprise (SME) and mill level). 


\section{Aims of the Study}

In accordance with the jointly identified goals of the UEM-Aalto cooperation and capacity development priorities, the aims of this study encompassed the following:

- To identify and agree upon the structure and key contents of the new module taking into account local sustainability priorities and concerns.

- To review and evaluate suitable teaching approaches and pedagogical choices.

- To consider national sustainable development priorities considering the viewpoints and concerns of both private and public stakeholders and interest groups.

\section{Material and Methodology}

The main methods were implementation of an extensive questionnaire and arrangement of a workshop on the development of the industrial environmental engineering study module. The participants of the workshop included government representatives (National Directorate of Land and Forest of the Ministry of Agriculture, National Directorate of Environmental Impact Assessment of Ministry for Coordination of Environmental Action), private sector (Green Resource and JM Sawmill), research institutions (Mozambican Agrarian Research Institute), academia staff (lecturers and MSc students of public and private higher education institutions) as well as expert representative of the Finnish Embassy in Maputo. The arranged workshop engaged UEM staff and key stakeholders in an intensive module development process and it succeeded in gaining valuable contributions from all involved actors to both structure/content development and teaching/pedagogical approaches. The structure of the applied questionnaire approach encompassed the following key sections:

1. Careful evaluation and weighing by percentage of the 1) key topic areas and 2) various themes.

2. Gathering of individual opinions and respondent suggestions on potential new themes and desired teaching methods and pedagogical choices.

3. The perspectives of the respondents on the sustainability themes that should be in the new module and innovative ideas on thesis projects and skills development.

The starting point was the idea to develop a 3 ECTS (EC, 2017) module for the MSc Programme in Wood Technology (Table 1) including additional supervised exercise and laboratory work amounting to 1 ECTS. Lecturing was planned to initially encompass lecturers from both universities and gradually only from UEM to highlight the importance of local skills and expertise. The draft structure (Table 2) of the new module loosely followed the 10 individual topics based on the chapters of a course book (Laukkanen et al., 2014) used in some Aalto courses. The chosen approach for the whole development process was to address sustainability concerns as perceived by both public and private sectors with due focus on all dimensions of sustainability. Thus, field trips and company visits were part of the agenda from the very beginning. 
Table 1. Wood Technology MSc. study plan. $\mathrm{H}=$ total contact hours, $\mathrm{h}=$ hours per week, $\mathrm{EI}=$ exercise and individual study hours, HT = total study hours and C = credits in ECTS.

\begin{tabular}{|c|c|c|c|c|c|c|c|}
\hline Year & Period & Module & $\mathrm{H}$ & $\mathrm{h}$ & E I & HT & $\mathrm{C}$ \\
\hline \multirow{20}{*}{$1^{\text {st }}$ Year } & \multirow{6}{*}{$1^{\text {st }}$} & Applied Statistic & 55 & 5 & 95 & 150 & 5 \\
\hline & & Research Methods & 33 & 3 & 57 & 90 & \\
\hline & & Wood Anatomy, Properties and Utilization & 66 & 6 & 114 & 180 & 6 \\
\hline & & Natural Forest Management & 33 & 3 & 57 & 90 & 3 \\
\hline & & Seminar I & 11 & 1 & 19 & 30 & 1 \\
\hline & & Sub-total & 187 & 17 & 289 & 476 & 17 \\
\hline & \multirow{5}{*}{$2^{\text {nd }}$} & Research Methods & 187 & 18 & 353 & 540 & 15 \\
\hline & & Wood Mechanical Processing & 33 & 3 & 57 & 90 & \\
\hline & & Wood Drying & 66 & 6 & 114 & 180 & 6 \\
\hline & & Wood Products Design I & 44 & 4 & 76 & 120 & 4 \\
\hline & & Sub-total & 44 & 4 & 76 & 120 & 4 \\
\hline & \multirow{7}{*}{$3^{\text {rd }}$} & Research Methods & 22 & 2 & 38 & 60 & 8 \\
\hline & & Wood Biodegradation and Preservation & 33 & 3 & 57 & 90 & 3 \\
\hline & & Wood Products Design II & 44 & 4 & 76 & 120 & 4 \\
\hline & & Business Management & 55 & 5 & 95 & 150 & 5 \\
\hline & & Optional/elective module & 33 & 3 & 57 & 90 & 3 \\
\hline & & Seminar II & 11 & 1 & 19 & 30 & 1 \\
\hline & & Sub-total & 198 & 18 & 342 & 540 & 24 \\
\hline & \multirow[t]{2}{*}{$4^{\circ}$} & Project Simulation & 150 & 30 & 60 & 210 & 7 \\
\hline & & Total ( $1^{\text {st }} \quad$ Year $)$ & 722 & & 1078 & 1800 & 60 \\
\hline $2^{\text {nd }}$ Year & & Dissertation & & & 1800 & 1800 & 60 \\
\hline TOTAL & & & & & & & 12 \\
\hline
\end{tabular}

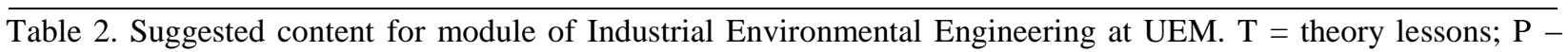
Practical lessons and exercises.

\begin{tabular}{|c|c|c|c|c|c|}
\hline \multirow[t]{2}{*}{ THEMES } & & \multicolumn{2}{|c|}{$\begin{array}{l}\text { Direct } \\
\text { contact }\end{array}$} & \multirow[t]{2}{*}{$\begin{array}{l}\text { Self } \\
\text { study }\end{array}$} & \multirow[t]{2}{*}{$\begin{array}{l}\text { Tot } \\
\text { al }\end{array}$} \\
\hline & & $\mathrm{T}$ & $\mathrm{P}$ & & \\
\hline & Introduction and general concepts & 2 & & & 2 \\
\hline & Environmental challenges & 3 & 5 & 4 & 12 \\
\hline & Climate change & 2 & 3 & 4 & 9 \\
\hline & Air emissions control & 2 & 2 & 5 & 9 \\
\hline & Control of noise and odour & 2 & 2 & 2 & 6 \\
\hline & Water and wastewater treatment & 2 & 3 & 5 & 10 \\
\hline & Waste management and use of residual streams & 3 & 3 & 5 & 11 \\
\hline & Environmental hazards and contaminants & 2 & 3 & 4 & 9 \\
\hline \multirow{2}{*}{\multicolumn{2}{|c|}{$\begin{array}{l}\text { 9. Environmental steering (legal, regulative, voluntary etc. } \\
\text { and management) }\end{array}$}} & 3 & 5 & 4 & 12 \\
\hline & & 2 & 3 & 5 & 10 \\
\hline \multicolumn{6}{|c|}{ 10. Sustainability and life cycle assessment } \\
\hline TOTAL & & 23 & 29 & 38 & 90 \\
\hline
\end{tabular}




\section{Results}

Maputo workshop participants included government representatives from Mozambican land and forestry and the environmental sectors, members from private enterprises, agrarian research institutions, embassy expert and lecturers and students from academia. The activities of the workshop encompassed brief presentation of the overall study programme and the specic new module and its objectives. Moreover, the floor was open for discussion and suggestions about the module structure and contents.

Based on the obtained results, the three most important focus areas (Table 3) were 1) sustainable use of natural resources, 2) environmental conservation and biodiversity and 3) chemicals, hazardous waste management and environmental toxins. These key results suggest that sustainable approaches, environmental concerns and addressing risks to the environment were particularly important. Moreover, legal aspects, appropriate technical skills and overall environmental management were essential. The suggested module structure after the workshop is presented in Table 4. The discussions at the workshop resulted in the following suggestions and recommendations:

- There should be a locally relevant legal component as an early theme in the module.

- Carbon market and other market related issues should be considered as a separate theme.

- The private sector and other institutions should have a clear role in the module activities.

- The order and arrangement of module themes should be further developed to be holistic and logical.

Table 3. Workshop results for Part 2: Importance of the different themes and topics. Rating is on a numerical scale from 0 to 5 where 5 indicates essential core knowledge, 3 somewhat important topics and 0 hardly worth covering in this context.

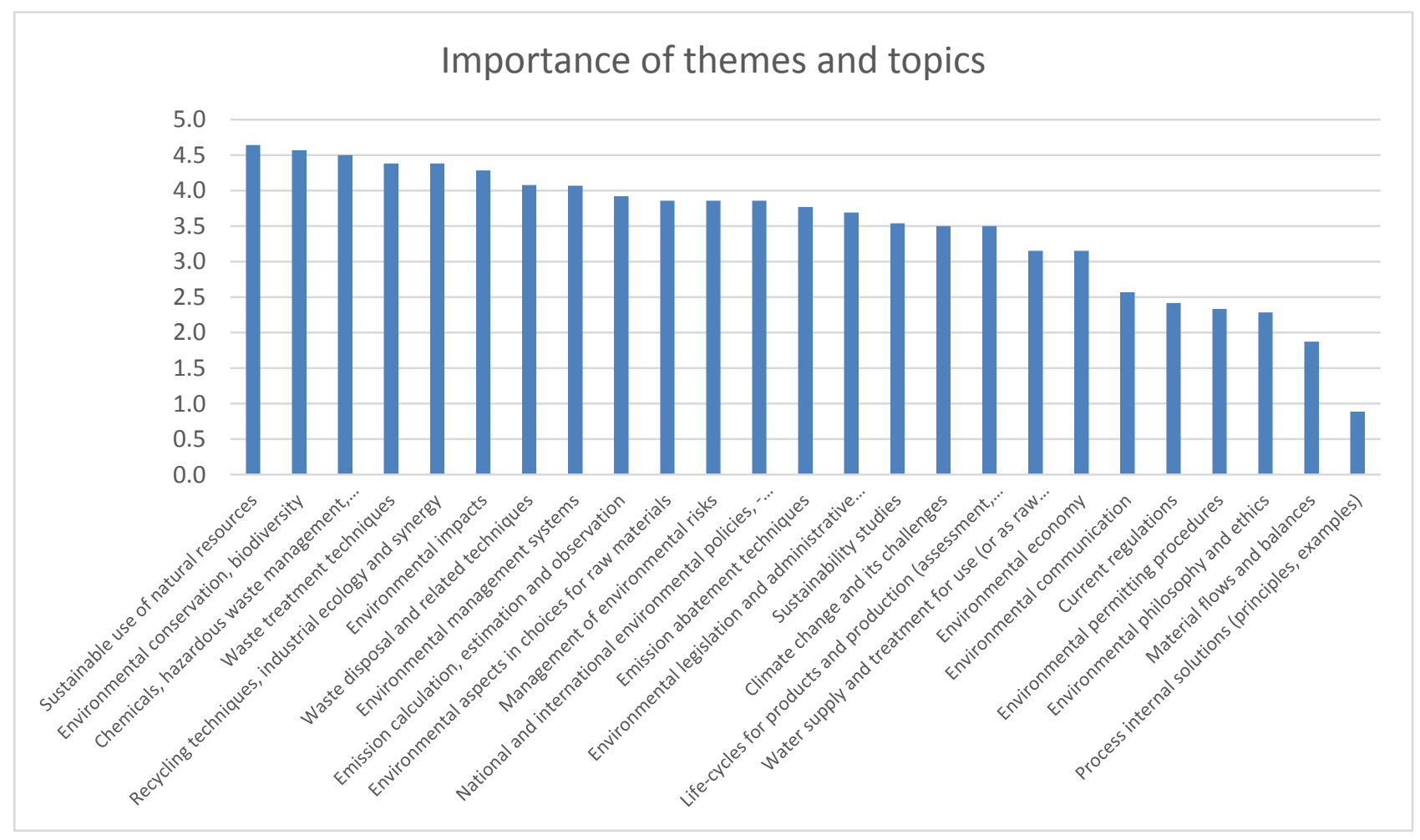


Table 4. Edited version of the module

\begin{tabular}{|c|c|c|c|c|c|}
\hline \multirow[t]{2}{*}{ THEMES } & & \multicolumn{2}{|c|}{$\begin{array}{l}\text { Direct } \\
\text { contact }\end{array}$} & \multirow[t]{2}{*}{$\begin{array}{l}\text { Self } \\
\text { study }\end{array}$} & \multirow[t]{2}{*}{$\begin{array}{l}\text { Tot } \\
\text { al }\end{array}$} \\
\hline & & $\mathrm{T}$ & $\mathrm{P}$ & & \\
\hline \multirow[t]{2}{*}{1 . } & \multirow{2}{*}{$\begin{array}{l}\text { Introduction and general concepts. Environmental challenges, hazards } \\
\text { and contaminants. }\end{array}$} & 4 & 5 & 6 & 15 \\
\hline & & 3 & 2 & 4 & 9 \\
\hline 2. & Environmental legislation. & 2 & 3 & 4 & 9 \\
\hline 3. & Climate change. & 3 & 3 & 4 & 10 \\
\hline 4. & Air emissions control. Control of noise and odour. & 2 & 3 & 4 & 9 \\
\hline 5. & Water and wastewater treatment. & 3 & 3 & 4 & 10 \\
\hline & $\begin{array}{l}\text { Waste management and use of residual streams. Occupational safety } \\
\text { and related topics. }\end{array}$ & 4 & 4 & 7 & 15 \\
\hline 7. & Sustainability and life cycle management and assessment of wood & 3 & 4 & 6 & 13 \\
\hline
\end{tabular}
based products.

8. Economic aspects, voluntary steering and market related topics. Environmental management.

The group work sessions produced the following suggestions:

- General legal issues must be included in the first theme (introduction and general aspects) and specific legal issues should be discussed in each theme of the module (in addition, it was recommended that a discussion of legislation concerning other related areas should also be included).

- Economic aspects should be presented as a separate theme encompassing the carbon market as well as other market approaches such as the market for certified forest products.

- The role of the private sector should encompass support of practical activities (e.g. field assignments) and work and thesis opportunities for students.

- The private sector and public institutions could send their staff to be trained by the UEM in the field of the module and its specific themes.

- The private sector is interested in partnerships with the UEM encompassing e.g. practical application of environmental and sustainability management tools.

\section{Discussion}

Previous studies have addressed many key elements and prerequisites for higher education in the field of sustainability, environmental issues and forest-related aspects. African indigenous knowledge systems need to be incorporated into higher education and the development of associated curriculum (Mubangizi and Kaya, 2015). In addition, more research efforts are needed in the field of indigenous knowledge systems with special emphasis on their role in sustainable development and advancement of sustainability e.g. in education (Breidlid, 2009). Allenby (2011) concluded that responsibility, the institutional, cultural, social and environmental context and system level implications are important in engineering and Abraham (2006) noted the community engagement is advised in addition to life cycle thinking and consideration of environmental impacts. Rosen (2013) summarized that it is important to develop sustainable practices supported by laws and standards and to engage both companies and customers. Allen and Shonnard (2011) noted the importance of performance metrics (i.e. the application of environmental, economic and social indicators). Learning and education for sustainable development requires holistic approaches (Dimenäs and Alexandersson, 2012; Scott and Gough, 2003) and proper understanding of complexities within interconnected systems considering long-term orientation and broad-based collaboration among different actors (Frisk and Larson 2011). More sustainable learning and improved pedagogy can be promoted through collaborative design of learning objects and collaborative learning activities (Vartiainen et al., 2012; Vartiainen and Enkenberg, 2013). Pedagogically, different learning levels can be promoted through a mix of approaches such as lectures, case studies and project-based learning (Bielefeldt, 2013). 
Paehlke (2005) stated the sustainability is about learning in an integrated way. The United Nations Educational, Scientific and Cultural Organization (2005) has outlined that education for sustainable development includes capacity-building for long-term and future-oriented thinking and decision-making as well as integration of sustainable development into other disciplines (UNESCO, 2005). Addressing sustainability challenges and understanding of complexity requires systems-thinking and the emerging sustainability curricula and education paradigm in higher education needs to encompass more cooperative approaches such as integrated dialogue among industry, academia and government (Weinstein et al., 2012). The possibility to choose sustainability studies in higher education has increased in recent years, particularly in North America (Cohen, 2011). At the Aalto University (2017), the aim is to integrate sustainability and responsibility into all teaching and research activities as well as to promote e.g. sustainable campus goals and outreach to societies efforts.

\section{Conclusions}

We determined the key elements of industrial environmental engineering based on local development priorities in Mozambique with strong emphasis on addressing existing and emerging sustainability challenges. The developed new module and associated curriculum are based on these results. Moreover, we jointly developed appropriate teaching and pedagogical approaches to suit the present needs of all involved parties. Linkages to national sustainable development priorities were identified and we engaged both private and public stakeholders to take part in the development of the module and related activities. Thus, the capacity of the UEM to provide higher education in the field of environmental engineering has been significantly improved and its MSc programme now covers both environmental and sustainability management aspects. All this is highly relevant since addressing sustainability challenges in Mozambique requires an input from higher education sector and skilled experts are needed in both public and private sectors. Sustainable use of natural resources and promotion of forest sector sustainability are very timely topics including the need to explore locally sustainable approaches. Industrial development and local companies also need a strong sustainability basis to be able to sustain their activities in the long-run in terms of environmental, economic and social aspects.

Based on our experiences, the development of higher education for sustainability and environmental management requires broad-based participation and engagement of multiple stakeholders from public and private sectors with sufficient emphasis on real-life and practical aspects. Moreover, higher education for forest sector sustainability requires focus on local level sustainability aspects jointly with broader national and international issues and integration of both private and public sector perspectives in a balanced manner. The developed new module should be relevant with respect to addressing existing and emerging national sustainable development challenges encompassing environmental, economic and social aspects. Regarding practical implications, we have consulted and visited companies in the forest sector both in Mozambique and in Finland after the module development work including specific thesis tasks for Mozambican MSc students in the field of our joint module. In addition, companies in Mozambique have expressed their interest in taking part in intensive training in industrial environmental engineering and sustainability provided by UEM and Aalto. The UEM MSc students have reported that their employment situation was significantly improved by our collaboration including training and partial thesis work in Finland. In the future, we plan to draft policy and company briefs based on our experiences and findings.

\section{Acknowledgements}

The research and development work presented in this article was carried out during the "VAGALHÃO" (Higher education and capacity-development for sustainability and clean technologies in the forest sector in Mozambique) project within the international development cooperation programme for higher education funded by the Ministry for Foreign Affairs of Finland.

\section{References}

Aalto University. (2017a). Sustainability at Aalto University. Retrieved from http://www.aalto.fi/en/about/reports_and_statistics/sustainability/

Aalto University. (2017b). Higher education and capacity-development for sustainability and clean technologies in the forest sector in Mozambique. Project Blog. Retrieved March 4, 2017, from https://blogs.aalto.fi/vagalhao/

AFLEG 2003. Africa Forest Law Enforcement and Governance (AFLEG) Ministerial Conference 13-16 October, 2003. Ministerial Declaration, Yaoundè, Cameroon, October 16, 2003.

Allen, D.T. \& Shonnard, D.R. (2011). Sustainable Engineering: Concepts, Design and Case Studies. Prentice Hall. 
Allenby, B., Allen, D., \& Davidson, C. (2007). Sustainable engineering: From myth to mechanism. Environmental Quality Management, 17(1), 17-26. https://doi.org/10.1002/tqem.20148

Allenby, B.R. (2011). The Theory and Practice of Sustainable Engineering. Prentice Hall: Upper SaddleRiver, NJ, USA.

Bielefeldt, A.R. (2013). Pedagogies to achieve sustainability learning outcomes in civil and environmental engineering students. Sustainability, (5), 4479 - 4501. https://doi.org/10.3390/su5104479

Breidlid, A. (2009). Culture, indigenous knowledge systems and sustainable development: a critical view of education in an African context. International Journal of Educational Development, 29(2), 140-148. https://doi.org/10.1016/j.ijedudev.2008.09.009

Cohen, S. (2011). Sustainability Management : Lessons from and for New York City, America, and the Planet. Columbia University Press. Ingram Digital.

Dimenäs, J. \& Alexandersson, M. (2012). Crossing disciplinary borders: perspectives on learning about sustainable development. Journal of Teacher Education for Sustainability, 14(1), 5-19. https://doi.org/10.2478/v10099-012-0001-0

EIA 2013. First Class connections. Log smuggling, illegal logging and corruption in Mozambique. Environmental Investigation Agency. This document was produced with the financial assistance of the Department for International Development (DFID) Forest Governance Markets and Climate programme.

European Commission. (2017). European Credit Transfer and Accumulation System. Retrieved from http://ec.europa.eu/education/resources/european-credit-transfer-accumulation-system_en

FAEF 2013. Assessment of harvested volume and illegal logging in Mozambican natural forest. A report of the Faculty of Agronomy and Forestry Engineering, Eduardo Mondlane University, Ave Julius Nyerere, Campus Universitário. Maputo, Mozambique, October, 2013. This report was prepared with support from the Forest Law Enforcement, Governance and Trade Support Programme for African, Caribbean and Pacific Countries (GCP/INT/064/EC).

Frisk, E. \& Larson, K.L. (2011). Educating for sustainability: Competencies and practices for transformative action. Journal of Sustainability Education, (2), 1-20.

Human Development Index. (2013). Retrieved from http://hdr.undp.org/en/statistics/hdi/

Laukkanen, T., Dahl, O. \& Martikka, M. (2014). Environmental Management and Engineering. Clean Technologies Research Group, Department of Forest Products Technology, School of Chemical Technology, Aalto University. $414 \mathrm{p}$.

Mubangizi, J. and Kaya, H. (2015). African indigenous Knowledge systems and human rights: implications for higher education, based on the South African Experience. International Journal of African Renaissance Studies - Multi-, Inter- and Transdisciplinary, 10(2), 125-142. https://doi.org/10.1080/18186874.2015.1107985

Nhantumbo, I., Macqueen, D.J., Cruz, R. \& Serra, A. (2013). Investing in locally controlled forestry in Mozambique: Potential for promoting sustainable rural development in the province of Niassa. IIED, UK.

Oyetunji, C.O. (2011). Reorienting leadership styles for sustainable education. Journal of Teacher Education for Sustainability, 13(2), 59-69. https://doi.org/10.2478/v10099-011-0014-0

Paehlke, R. (2005). Sustainability as a Bridging Concept, Conservation Biology, 19(1), 36-38. https://doi.org/10.1111/j.1523-1739.2005.00426.x

Plan of Action for the Green Economy. (2013). Retrieved from http://allafrica.com/stories/201310170958.html

Rosen, M.A. (2012). Engineering sustainability: A technical approach to sustainability. Sustainability, 4(9), 2270-2292. https://doi.org/10.3390/su409227

Rosen, M.A. (2013). Engineering and sustainability: attitudes and actions. Sustainability, (5), 372-386. https://doi.org/10.3390/su5010372

Scott, W. and Gough, S. (2003). Sustainable development and learning: framing the issues. RoutledgeFalmer. https://doi.org/10.4324/9780203464625

UN. (2013a). The Millennium Development Goals. Retrieved from http://www.un.org/millenniumgoals/ 
UN. (2013b). UN $\quad$ Mozambique. $\quad$ Retrieved from http://mz.one.un.org/eng/What-we-do/About-the-Millennium-Development-Goals/MDGs-in-Mozambique

UNESCO. (2005). United Nations Decade of Education for Sustainable Development

(2005-2014). Draft international implementation scheme. Janurary 2005. United Nations Educational, Scientific and Cultural Organisation.

UN-REDD. (2013). UN-REDD $\quad$ Programme. $\quad$ Retrieved from http://www.un-redd.org/AboutREDD/tabid/102614/Default.aspx

Vartiainen, H. \& Enkenberg, J. (2013). Reflections of design-oriented pedagogy for sustainable learning: an international perspective. Journal of Teacher Education for Sustainability, 15(1), 57-72. https://doi.org/10.2478/jtes-2013-0004

Vartiainen, H., Liljeström, A., \& Enkenberg, J. (2012). Design-oriented pedagogy for technology-enhanced learning to cross over the borders between formal and informal environments. Journal of Universal Computer Science, 18(15), 2097-2119.

Weinstein M., Turner R., \& Ibáñez C. (2012). The global sustainability transition: it is more than changing light bulbs. Sustainability: Science, Practice \& Policy, 9(1), 4-15.

World Bank. (2017). Mozambique $\quad$ overview. Retrieved from http://www.worldbank.org/en/country/mozambique/overview

Worldwide Governance Indicators. (2012). Mozambique 1996-2012. Retrieved from http://info.worldbank.org/governance/wgi/pdf/c149.pdf 